\title{
ARTICLE \\ Advancing justice interests and human rights of vulnerable groups through clinical legal education
}

\author{
Marium Jabyn ${ }^{1}$
}

Accepted: 21 December 2020 / Published online: 11 February 2021

(c) O.P. Jindal Global University (JGU) 2021

\begin{abstract}
Access to justice rights of vulnerable groups in the Maldives is significantly affected due to lack of information, awareness, accessibility, and legal representation. The provision of State-funded legal aid is only available in serious criminal cases, and free legal services provided by individual lawyers and civil society organisations are limited and scattered. Out of 20, only a handful of atolls in the Maldives have resident lawyers offering legal services. Thus, as a country with over 200 inhabited islands, key vulnerable groups such as women and children face serious challenges in attaining legal services and access to the system. This article emphasises the broader objectives of legal education and argues that by pursuing social justice goals and advancing the human rights of vulnerable groups in the Maldives, university law clinics can benefit legal education and the society at large.
\end{abstract}

Keywords Legal education - Law clinic - Access to justice · Vulnerable groups · Legal aid

\section{Introduction}

Access to justice rights of vulnerable groups in the Maldives is significantly affected due to lack of information, awareness, accessibility, and legal representation. The provision of State-funded legal aid is only available in serious criminal cases, and free legal services provided by individual lawyers and civil society organisations are limited and scattered; out of 20, only a handful of atolls in the Maldives have resident lawyers offering legal services. Thus, as a country with over 200 inhabited islands, key vulnerable groups such as women and children face serious challenges in attaining legal services and access to the system. This article argues that law schools globally are exploring experiential learning methods and are developing

* Marium Jabyn

mjabyn@gmail.com

1 Founder and Chairperson, Equal Rights Initiative and current Secretary General, Bar Council of the Maldives, Malé, Republic of Maldives 
community-based legal aid and access to justice programmes, with a view to enhancing human rights. While such initiatives are fairly young in South Asia, many countries have developed successful programmes, particularly in rural areas, and facilitated access to legal and justice systems. The final aim of the article is to emphasise the broader objectives of legal education and argue that by pursuing social justice goals and advancing human rights of vulnerable groups in the Maldives, university law clinics can benefit legal education and the society at large.

\section{Defining justice interests}

A number of access to justice studies conducted in the Maldives between 2007 and 2017 reveal that disparities between the law and citizens' awareness of rights, lack of knowledge of the law, pervasive discrimination, discrimination based on gender and nationality are key obstacles facing the local population in accessing justice. ${ }^{1}$ It was also found that access to justice is also impeded by procedural and geographical barriers which prevent victims and vulnerable groups from accessing services in the capital and city regions, and lawyers from travelling to remote islands to provide services to clients or victims. Affordability of travel and fees adds another dimension to the impossibility of receiving timely legal services and justice. ${ }^{2}$

Legal aid and legal assistance have presented a significant barrier for vulnerable groups, such as women, who note that the number one reason affecting access to justice for them is the lack of access to lawyers, followed by difficulties in filling service and court application forms. ${ }^{3}$ Additionally, over 80 per cent of the women who took part in this study also noted that access to legal information presents a key barrier to access to justice, ${ }^{4}$ and that this prevents them from pursuing protections and legal remedies otherwise guaranteed under various legislations put in place for the protection of vulnerable groups such as the sexual offences act, domestic violence act, social protection act, sexual abuse and harassment prevention act. ${ }^{5}$ Women also note that lack of awareness of the system and the cost of legal services also present key challenges for women to access justice. ${ }^{6}$

\footnotetext{
1 See United Nations Development Programme (UNDP), Access to Justice Assessments in the Asia Pacific: A Review of Experiences and Tools from the Region (UNDP Asia-Pacific Regional Centre, Bangkok, February 2012); UNDP, Sharing Experience in Access to Justice - Engaging with Non-State Justice Systems \& Conducting Assessments, Access to Justice Week Summary of Presentations and Discussions, October 2010 (UNDP Asia-Pacific Regional Centre, Bangkok, January 2012).

2 Attorney General's Office and UNDP, Legal and Justice Sector Baseline Study 2014 (Attorney General's Office and the UNDP, Maldives, 2015); UNDP, Research on Maldives Women's Access to Justice 2017 (UNDP, Maldives, 2017).

${ }^{3}$ UNDP, Research on Maldives Women's Access to Justice 2017 (n 2) 53.

4 Ibid. 53.

5 Ibid. 53.

6 Ibid. 46.
} 
While it is extremely difficult to access lawyers in the islands, it is also noted that a limited percentage of the population is aware of what legal aid is, and how to apply for legal aid. ${ }^{7}$ While the same study shows that women did not need legal aid, it fails to adequately note and reflect the factual situation that legal aid in the Maldives is offered by the State and is limited to matters of serious criminal offences, and that women's legal aid need is in civil matters and in the family court, and not in serious criminal cases. ${ }^{8}$ Thus, given the high cost, and lack of economic independence of women, over 70 per cent of women choose not to pursue legal recourse, and prefer an out-of-court settlement for their legal issues. ${ }^{9}$

For women, a key factor which affects their access to justice is gender, which, although much discussed in national forums, appears to have received little to no attention from policymakers. Access to justice for women, therefore, must begin by addressing these legal and structural barriers, and must empower women to pursue equal rights. While the 2008 Constitution has introduced a clear statement on the prohibition of any form of discrimination based on gender, there are pervasive and continuing gender inequalities in the legal and justice system in the Maldives. ${ }^{10}$ There are multiple laws in the Maldives which either directly discriminate against women, or create a position of vulnerability for women by the implementation of the law. Family Law Act, 2001 and the Sexual Offences Act, 2013 are the best examples in this context. In 2013, the UN Special Rapporteur visited the Maldives and noted that while the Constitution has created progressive changes in the Maldives, there is a lack of policy and strategy to address the gender bias in the system. ${ }^{11}$ According to Knaul:

The approach of the judiciary in general is quite conservative and representative of a very traditional and patriarchal societal structure. Gender biases and discriminatory attitudes and practices are widespread within the judiciary and the administration of justice ... sustained and comprehensive sensitization and awareness-raising programmes on gender equality and women's rights are urgently needed for all State institutions, including the judiciary, prosecutors and lawyers, in order to push for change regarding patriarchal and discriminatory attitudes and practices and make access to justice a reality for women in the Maldives. ${ }^{12}$

\footnotetext{
7 UNDP, Legal and Justice Sector Baseline Study 2014 and Research on Maldives Women's Access to Justice 2017 (n 2).

${ }^{8}$ Court statistics in the Maldives show that the clientele of the Family Court is largely women, and this indicates that women's engagement with the law is largely in non-criminal matters, and mostly in matters of family law, marriage, divorce, and social protection.

9 UNDP, Research on Maldives Women's Access to Justice 2017 (n 2) 27-28.

10 See generally, M Jabyn, Local Implications of International Human Rights Treaties: The Impact of a CEDAW Right to Public Life in the Republic of Maldives (Doctor of Philosophy thesis, University of Waikato, New Zealand 2016).

11 United Nations General Assembly, Human Rights Council Twenty-Third Session, Report of the Special Rapporteur on the Independence of Judges and Lawyers (Mission to the Maldives), Gabriela Knaul, (A/HRC/23/43/Add.3), 21 May 2013, 17.

12 Ibid.
} 
The Rapporteur further noted that women are not sufficiently educated about their rights and are subjected to social stigma, sexual and domestic violence, and yet they do not bring their cases to court because they do not trust the courts. ${ }^{13}$ Amongst other recommendations concerning women, the State has yet to effectively work on 'eliminating gender discrimination in the justice system by focusing on training judges, magistrates, lawyers, and prosecutors on gender equality and women's rights, and general awareness raising on women's rights, including awareness on new legislation such as the Domestic Violence Act'. ${ }^{14}$ The State is also yet to adopt a policy on encouraging and enhancing the presence of women in the legal profession, prosecution, or the judiciary. ${ }^{15}$ Thus, in addition to the lack of a comprehensive legal aid system that captures vulnerable groups, ${ }^{16}$ there are other significant barriers to human rights and access to justice for women in the Maldives.

\subsection{The provision of legal aid and its limits}

Legal aid can be facilitated through the provision of State-funded legal aid services, pro bono lawyering, public interest litigation, paralegal services, and informal justice mechanisms. While legal aid must be targeted at vulnerable members of the society, regardless of the type of case, whether of criminal or civil nature, State-funded legal aid in the Maldives is only available in criminal matters, which is primarily aimed at fulfilling a constitutional obligation to provide free criminal defence in cases of serious criminal offences. New legislations which came in 2019 such as the Legal Profession Act also seek to support the State institutions in matters of legal aid in serious criminal offences only. ${ }^{17}$ Thus, to date, there is no existing legislative provision or right to legal aid for non-criminal matters in the Maldives, ${ }^{18}$ and in the absence of any reform in this area of the law and social services, it suggests that family law reform and legal aid in non-criminal legal matters, pivotal for the women's justice agenda, are not current national priorities. While there is a total lack of informal justice mechanisms in the Maldives, pro bono lawyering and paralegal services are largely limited to the central capital region of the country, and to clients who have access to these lawyers in the capital. Thus, there is a severe need for adequate legal services in the outer atolls.

\footnotetext{
${ }^{13}$ Ibid; also see United Nations Human Rights Committee, Consideration of Reports Submitted by State Parties under Article 40 of the Covenant, Concluding Observations adopted by the Human Rights Committee at its $105^{\text {th }}$ Session: Maldives, (CCPR/C/MDV/CO/1), 31 August 2012, 11; United Nations Committee on the Limitation of Discrimination against Women, Thirty-Seventh Session, Concluding Comments of the Committee on the Elimination of Discrimination Against Women: Maldives (CEDAW/C/ MDV/CO/3), 2 February 2007, 19.

${ }^{14}$ United Nations General Assembly, Human Rights Council Twenty-Third Session, Report of the Special Rapporteur on the Independence of Judges and Lawyers (Mission to the Maldives), May 2013, 22.

15 Ibid.

${ }^{16}$ UNDP Maldives Report, 'Options for Legal Aid Programming in the Maldives', Working Paper Series, United Nations, 9.

${ }^{17}$ Legal Profession Act 2019, Sec. 5(h).

${ }^{18}$ Constitution of the Republic of Maldives, Art. 53(b).
} 
In 2012, UNDP Maldives funded a study of the legal aid system in the Maldives to make recommendations on appropriate models for legal aid based on international comparative studies. ${ }^{19}$ Amongst other issues, this study identified an acute need for legal services outside of Male in remote island areas, and the challenges presented in delivering such assistance across such vast distances, and inconsistent political will to fund a comprehensive free legal aid system, as key issues for legal aid. This study suggested, amongst others, a national legal aid commission aimed at coordinating all forms of criminal and civil legal aid and outreach; establishing a bar council for the regulation of the profession; instituting a system of compulsory pro bono legal services; pursuing legal information initiatives; establishing low-level first instance legal assistance which includes short-term initiatives such as helpdesks, hotlines, awareness campaigns, trainings, service provision, visits, and legal clinics; and establishment of legal aid clinics and mobile services which could include legal assistance by less expensive paralegals through public-private partnerships and NGOs. ${ }^{20}$

In 2016, UNDP Maldives, in partnership with the Attorney General's Office and the Family Protection Authority, initiated a national discussion on the topic, and held the first national conference aimed at establishing a pro bono mechanism to enhance the accessibility of legal aid services to vulnerable groups in the Maldives. ${ }^{21}$ The conference discussed the State's constitutional obligation to provide legal aid in serious criminal offences, but aimed at going beyond the constitutional obligation to address the issue of legal aid as a necessary component of access to justice. The conference noted the importance of exploring alternative legal aid mechanisms in the Maldives, and pooling of resources by government, private sector, and civil society organisations in providing legal aid services.

In 2018, private legal practitioners in the Maldives took this initiative further and conducted a series of 'Pro Bono Roundtable Conferences' to discuss ways of strengthening and enhancing the provision of pro bono services provided by law firms and practitioners in the Maldives. ${ }^{22}$ The first of these round tables was led by the law firm Hisaan, Riffath \& Co. in collaboration with Munavvar \& Associates Law Firm, and the second conference was held by the Maldives Law Institute, in collaboration with Muizzu \& Co. LLP. The third of these law firm initiatives was led by Premier Chambers, which also expanded the round table to include civil society organisations, and discussed options for strengthening collaborations between the legal fraternity and the civil society organisations. Participants of this conference agreed to adopt a clearing house, and discussed the format of the clearing house which mainly aimed to support existing initiatives of the State and those provided by private organisations, and collaborate with island-level community organisations. ${ }^{23}$

\footnotetext{
${ }^{19}$ UNDP Maldives, 'Options for Legal Aid Programming in the Maldives' (n 16) 9.

20 Ibid. 7.

21 'UNDP Press Release: First National Legal Aid Conference Held' (19 July 2016). https://www. mv.undp.org/content/maldives/en/home/presscenter/pressreleases/2016/firstNationalLegalAidConferenc e.html. Accessed 10 November 2020.

22 Maldives Third Pro Bono Round Table Conference, 'The Way Forward' Report (September 2018) 3.

23 Ibid. 8.
} 
In the Maldives, NGOs also contribute significantly to enhancing legal aid. The first such formal initiative was established in June 2012, when Transparency Maldives established an Advocacy and Legal Advice Centre (ALAC) to provide free legal advice to victims and witnesses of corruption. The Centre also provided services to vulnerable Bangladeshi workers in the Maldives and conducted mobile ALAC camps in rural atolls providing free legal advice to the vulnerable communities in the islands with very limited access to legal services. Transparency Maldives is currently building on these efforts and working to address the employment issues and rights violations due to COVID-19 in the Maldives, which again will include the Bangladeshi population in the country. Family Legal Clinic (FLC) began as a legal aid provider of the local NGO Hope for Women. However, and with the broadening of its services, FLC is now registered as a separate NGO and provides pro bono legal consultations and awareness in the areas of family law and prevention of domestic violence law. ${ }^{24}$ The Public Interest Law Centre (PILC) has a mobile legal aid clinic that travels around the Maldives to assist island communities in getting access to justice by providing free legal aid and legal awareness. ${ }^{25}$ Other social rights NGOs also play a significant role in assisting vulnerable persons in attaining justice in the local system. ${ }^{26}$

While the State has a presence in the islands and is increasingly working towards the establishment of institutional structures, there is an unmet need for legal assistance for vulnerable groups. Private and personal legal services are very much confined to the capital city Malé and the greater Malé region. Island communities are thereby unable to access any services from a lawyer, or simple legal services, due to which even filing a simple case becomes an impossibility for many. Furthermore, despite the NGO initiatives, with the travel and cost of associated resources, meeting the service need across the country has been a nation-wide challenge. It is therefore envisaged that by ensuring availability of legal services in the islands and by empowering vulnerable groups, access to justice can be sufficiently improved in the local context. Moreover, given the current context, university-based law clinics present a promising option for the Maldives, because universities already have campuses across the country, and a university-based human rights clinic can provide support to vulnerable groups, and assist State agencies working in social protection.

\subsection{The promise of law clinics for human rights and legal education}

Law clinics are the ideal pedagogical medium to advance both legal education and human rights. The clinical education method is known to promote the essentials of

\footnotetext{
${ }^{24}$ Family Legal Clinic, www.familylegalclinic.org.mv. Accessed 10 November 2020.

25 Public Interest Law Centre, http://www.pilcmv.org/ Accessed 10 November 2020.

${ }^{26}$ Hassan Haneef, 'Easy Access to Justice for All Including Vulnerable Persons in the Maldives', in United Nations Asia and Far East Institute for the Prevention of Crime and the Treatment of Offenders, Resource Material Series No. 105 (168th International Senior Seminar, Participant Papers, September 2018). https://www.unafei.or.jp/publications/pdf/RS_No105/No105_1_ALL.pdf. Accessed 31 October 2020 .
} 
social justice by promoting access to justice for the underprivileged through representing them in various forms, by exposing law students to the responsibility of public service or pro bono work, and by creating an understanding of the relationship between law and social justice among the law students. ${ }^{27}$ Law clinics ensure that students are exposed to the outside realities of the communities in which they will function, and reconstruct their academic agendas accordingly. ${ }^{28}$ Clinics thus force law students to think beyond abstract principles and law school theories, and expand their visions of social justice, while at the same time embracing the evolving nature of their curriculum to focus on global human rights issues. ${ }^{29}$ According to Stephen Wizner, law school clinics are the ideal learning method in modern times because they teach both intellectual and ethical lessons to law students. He described the advantages in the following terms:

First and foremost, they learn that many social problems, like poverty, can be seen and acted upon as legal problems. Second, they learn that legal representation is as necessary to the resolution of complex legal problems of the poor as it is to those of the affluent. Third, they learn to develop and apply legal theory through the actual representation of clients. Fourth, they learn to use the legal system to seek social change. And finally, they learn the limits of law in solving individual and social problems. Through this experience the students are required to confront social and economic injustice, and to act on the professional obligation of lawyers to engage in public service and to provide legal assistance to those who cannot afford to pay for it. ${ }^{30}$

Marson et al. argue that law clinics provide a set of skills, otherwise largely unavailable throughout legal education. ${ }^{31}$ These skills, what they refer to as D-R-A-I$\mathrm{N}$ skills, focus on developing D-drafting, R-research, A-advocacy, I-interview, and $\mathrm{N}$-negotiation skills in students, which are key elements of clinical legal education (CLE). Law clinics not only teach these to students, but adopt various teaching methods to ensure that students are able to learn from doing, from experience, and are able to reflect and critically analyse what they have acquired as skills. Pedagogical approaches can also require students to grasp the transnational dimensions of legal practice because globalisation has a massive impact on the legal, political, and economic dimensions of sovereign States. ${ }^{32}$

\footnotetext{
${ }^{27}$ Jon C Dubin, 'Clinical Design for Social Justice Imperatives' (1997-1998) 51 SMU Law Review $1461,1475-1476$.

${ }^{28}$ Jocelyn Getgen Kestenbaum, Esteban Hoyos-Ceballos, and Melissa C Del Aguila Talvadkar, 'Catalysts for Change: A Proposed Framework for Human Rights Clinical Teaching and Advocacy' (2012) Clinical Law Review 460-463; Claudio Grossman, 'Building the World Community: Challenges to Legal Education and the WCL Experience' (2002) 17 American University International Law Review, 827.

${ }^{29}$ Johanna Bond, 'The Global Classroom: International Human Rights Fact-Finding as Clinical Method' (2001) 28(1) William Mitchell Law Review 319.

${ }^{30}$ Stephen Wizner, 'The Law School Clinic: Legal Education in the Interests of Justice' (2002) 70(5) Fordham Law Review 1935.

${ }^{31}$ See James Marson, Adam Wilson, and Mark Hoorebeek, 'The Necessity of Clinical Legal Education in University Law Schools: A UK Perspective' (2005) 7 International Journal of Clinical Legal Education 29.

${ }^{32}$ Deena R Hurwitz, 'Lawyering for Justice and the Inevitability of International Human Rights Clinics' (2003) 28 Yale Journal of International Law 505, 506.
} 


\subsubsection{Legal education: ideologies and realities}

The debate over the best way to teach law has existed just as long as legal education has existed. While there are two major opinions on the subject, one major viewpoint is that the apprenticeship model may give practical knowledge to students; however, it would not give them an understanding of the principles upon which rules of practice are founded. According to this approach, law should be studied as a broader discipline of study. ${ }^{33}$ The opposing view argues that law is a technical skill, and despite excellent teaching, can only be obtained from exposure to the actual business of law. ${ }^{34}$ Apprenticeships, therefore, continue to be a major part of the qualification to become a lawyer in the UK. ${ }^{35}$ Legal education in the US also began exclusively with apprenticeships and did not involve any formal education system, and is known to have produced the most famous lawyers in American history such as John Adams, John Marshall, Andrew Jackson, and Thomas Jefferson. ${ }^{36}$ The idea of a proper legal education was to create a generation of lawyers dedicated to public virtue, the greater good over one's individual interest. ${ }^{37}$

The case method, which adopts a Socratic style of teaching law, was introduced in the late 1800s and mirrored the technical work of a lawyer. This move from apprenticeships to teaching case law changed the course of legal education, which became more adversarial in nature, and made law personal and transactional, and focused on the individual as opposed to the wider social context. This style of legal education, with a focus on rules and case law, has since been adopted and followed as the primary method of legal education in the Western world. ${ }^{38}$ The result of the case method though was that law schools produced lawyers who applied the pure law, which prepared them to document rules without reasoning, and law was not to be questioned. This method has been criticised as representing a narrow view of legal education, ${ }^{39}$ producing legal monks who were disconnected from the societies

\footnotetext{
33 William Blackstone, 'Introduction', Commentaries on the Laws of England (Clarendon Press 17651769); also see Christopher Brooks and Michael Lobban (eds), Lawyers, Litigation and English Society Since 1450 (Bloomsbury 1998) 153; Anthony T Kronman, History of the Yale Law School: The Tercentennial Lectures (Yale University Press 2008) 20.

${ }^{34}$ AV Dicey, 'Can English Law Be Taught at the Universities?' (Inaugural Address at All Souls College, 21 April 1883) 7-8.

35 Andrew Boon and Julian Webb, 'Legal Education and Training in England and Wales: Back to the Future' (2008) 58(1) Journal of Legal Education 83.

${ }^{36}$ Danielle Thorne, People That Changed the Course of History: The Story of Andrew Jackson, 250 Years after His Birth (Atlantic Publishing 2016); David M Douglas, 'Jefferson's Vision Fulfilled' (2010) William \& Mary Alumni Magazine. https://scholarship.law.wm.edu/popular_media/3/.Last Accessed 31 October 2020.

${ }^{37}$ Paul D Carrington, 'The Revolutionary Idea of University Legal Education' (1990) 31 William and Mary Law Review, 528; Douglas, 'Jefferson's Vision Fulfilled' (n 36).

${ }^{38}$ See the discussion in Joshua Krook, 'A History of Law Schools: A Battle between Law as a Science and Law as a Liberal Art' (2017) 17(2) Legal History 30.

${ }^{39}$ See generally Margaret M Barry, Jon C Dubin, and Peter A Joy, 'Clinical Education for This Millennium: The Third Wave' (2000) 7 Clinical Law Review 1, 5-6. See also Charles R McManis, 'The History of First Century American Legal Education: A Revisionist Perspective' (1981) 59 Washington University Law Quarterly 597.
} 
they were meant to serve, ${ }^{40}$ and therefore failing to produce lawyers with actual life skills.

A new legal realism wave of understanding law within social realities occurred in the US in the early 1900s, and changed law school teaching towards social realities and jurisprudence by introducing clinical programmes. ${ }^{41}$ The legal realists encouraged students to think about how and why law is created, whom it aims to serve, the role of lawyers and judges, to question existing legal rules and arrangements, and to propose law reform to address inadequacies in the system. ${ }^{42}$ Consequently, and as early as 1916, the New York State Bar Association adopted a resolution requiring that "every law school shall make earnest clinical work, through legal aid societies or other agencies, a part of its curriculum for its full course. ${ }^{43}$ Over the century, the movement for social relevance in the law school curriculum has brought CLE to the forefront, and the latter is increasingly accepted as the ideal legal education method to teach law and practice, and the life skills to serve the needs of the people and the system.

Prior to the Legal Profession Act, 2019, there were no standardised legal education requirements, apprenticeships, or professional exams to be completed to enter the legal profession in the Maldives. ${ }^{44}$ All law graduates would be licensed despite their class of graduation, or ability to practise law and provide legal services. Thus, law schools offering law degrees had no targets to be achieved in terms of skills or social justice goals. The first legal education programmes were greatly focused on training personnel in Shari'ah law used for adjudication purposes. Thus, the first local training for lawyers was initiated as a two-year programme at the Institute of Islamic Studies in 1988, and primarily taught Islamic law (Shari' ah) subjects. ${ }^{45}$ In the 1990s, the Maldives made significant efforts to establish its first formal law

\footnotetext{
${ }_{40}$ Robert Bocking Stevens, Law School: Legal Education in America from the 1850s to the 1980s (University of North Carolina Press 1983) 59.

41 The University of Harvard, University of Pennsylvania, University of Denver, George Washington University, University of Minnesota, and University of Tennessee established legal aid centres. See John S Bradway, 'The Nature of a Legal Aid Clinic' (1930) 3 Southern California Law Review 173, 174; William V Rowe, 'Legal Clinics and Better Trained Lawyers - A Necessity' (1917) 11 Illinois Law Review 591.

42 Wizner, 'The Law School Clinic' (n 30) 1931-1932.

43 Rowe, 'Legal Clinics and Better Trained Lawyers' (n 41) 595, quoted in Bruce Avery Lasky, 'Introduction: Clinical Legal Education and Its Asian Characteristics' in Shuvro Prosun Sarkar (ed), Clinical Legal Education in Asia: Accessing Justice for the Underprivileged (Palgrave Macmillan 2015) 2.

44 The various bodies that licensed lawyers in the Maldives prior to the Legal Profession Act (LPA) 2019 , followed basic regulations to license lawyers. The two most recent of which were those adopted by the Attorney General's Office and the Supreme Court of the Maldives. The Attorney General's Office's Regulation on Licensing Lawyers (2014/R-30), required a law graduate to have studied the common law subjects of contract law, criminal law, constitutional law, tort law, land law, and equity and trusts, in order to be licensed. The mandate was transferred to the Supreme Court in 2015, and the new regulation adopted by the Supreme Court, Regulation No. 2015/SC-RU/03, did not specify which subjects to be covered, and hence was more relaxed than the previous regulations on licensing lawyers. None of these regulations stipulated qualifying exams for Bar Admission.

45 Husnu Al Suood, The Maldivian Legal System (Maldives Law Institute 2014) 185-193.
} 
school, the Institute of Shari' ah and Law (currently Faculty of Shari'ah and Law, Maldives National University). The programmes introduced by the Malaysian Asian Development Bank (ADB) consultants who were hired to develop the law degree, and followed to date, are greatly influenced by the Malaysian legal education tradition, incorporating both common law subjects and Shari'ah law subjects. The first local law graduates of this institution graduated with their degrees in $2004,{ }^{46}$ and today, law is offered as an undergraduate degree in five academic institutions in the Maldives. A large majority of these law schools continue to offer a law degree which teaches both common law and Shari'ah law subjects, catering to the mixed legal system in the Maldives. With less than 20 years of history, formal legal education is in its infancy in the Maldives. Law degree programmes are largely aimed at imparting heavy doctrinal academic knowledge, with the complete exclusion of all skillsrelated components. ${ }^{47}$ The local law degree programmes are, therefore, extremely bulky course programmes, and fall short in ensuring that law graduates learn and acquire lawyering skills and professional ethics at law school.

The problems with legal education in the Maldives, however, go beyond the focus on legal knowledge. Students from the two biggest law schools in the country, the Maldives National University and the Islamic University of the Maldives, are offered all core and additional law modules offered at a regular Western law school programme, and the Shari'ah equivalent modules for these subjects. For example, students will be required to study both criminal law and Islamic criminal law. Julian Webb, in his recent assessment of the Maldives legal education system, noted that

"there is widespread recognition that the existing curriculum is overloaded ... the issue, moreover is not just quantitative. The Maldives curriculum will not be improved simply by teaching less; it also needs to teach some different things, and to teach differently, if it is to prepare students for the modern world of practice." 48

Furthermore, although some procedure is offered in a few local degree programmes, ${ }^{49}$ courses do not focus on the practice of law, nor on the broader social justice goals of lawyering. Law schools do not provide the opportunity to engage in independent and experiential learning through research projects and practical methods such as CLE and simulation exercises. ${ }^{50}$ Thus, a human rights and social justice aspect to lawyering is completely missing in the Maldives legal education landscape ${ }^{51}$ and even in the very recent assessment of legal education standards in the Maldives, experiential learning is not included as a mandatory part of legal education in the Maldives, ${ }^{52}$ and the value of such a programme for legal education in the Maldivian context has not been adequately considered.

\footnotetext{
${ }^{46}$ Marium Jabyn and Rogena Sterling, 'Better Lawyers, Better Justice: Introducing Clinical Legal Education in the Maldives' in Sarkar, Clinical Legal Education in Asia (n 43) 18.

47 Ibid.

48 Julian Webb, Assessment of the Legal Education Curriculum in the Maldives, Final Report (UNDP Maldives, 5 February 2020) 32.

49 Islamic University of the Maldives and Avid College Law School curricula.

50 Webb, Assessment of the Legal Education Curriculum in the Maldives (n 48) 28.

51 See Jabyn and Sterling, 'Better Lawyers, Better Justice' (n 46) 17.

52 See Webb, Assessment of the Legal Education Curriculum in the Maldives (n 48).
} 
While this type of law teaching and education, where the teachers impart knowledge and students are merely passive learners, is common to many Asian countries, ${ }^{53}$ the CLE movement is making promising progress globally ${ }^{54}$ and is expanding at a rapid space across Asia. ${ }^{55}$ The movement is developing legal knowledge, skills, ethics, and pro bono values in students, and simultaneously enhancing social justice, delivering legal assistance and empowerment of the poor and the marginalised. ${ }^{56}$ As such, it must be the next step in the advancement of legal education and human rights lawyering in the Maldives.

\subsubsection{Human rights lawyering and clinical programmes}

Louise G Trubek argued that critical lawyering involves two elements: seeking to empower oppressed groups and individuals and initiating a trajectory of change towards a more just society, and lawyers can empower societies in two ways: individually through supportive attorney-client relationships, and secondly through organised work to encourage individuals to speak out in the public sphere. ${ }^{57}$ Law clinics have been a part of simple social issues affecting societies, and have assisted individuals and organisations in major human rights cases. Many of these community initiatives start from a common standpoint that inequality is the single most important factor affecting human rights, and that community lawyering should support efforts to challenge social and economic inequalities in society.

Human rights lawyering demands active engagement, and teaches students the role of human rights norms, how legal theory and legal practice work, and the actual functioning of a legal system. ${ }^{58}$ Realising human rights for people involves an 'engaged critical consciousness that is developed through education, training, and community organising, as well as strategic lawyering, ${ }^{59}$ Collaborative lawyering also helps in developing legal skills ranging from civil litigation in defence of constitutional rights to criminal defence, and has thereby assisted in shaping representation based on community needs. ${ }^{60}$ Such training influences students to change the feelings of the body politic to promote greater obedience to international human

\footnotetext{
53 Cheng Han Tan, Gary Bell, Xuan Hop Dang, et al., 'Legal Education in Asia' (2006) 1 Asian Journal of Comparative Law 1.

54 Frank S Bloch (ed), The Global Clinical Movement: Educating Lawyers for Social Justice (Oxford University Press 2011).

55 Lasky, 'Introduction: Clinical Legal Education and Its Asian Characteristics' (n 43) 6.

56 Ibid.

57 Louise G Trubek, 'Critical Lawyering: Toward a New Public Interest Practice' (1991) 1 Boston University Public Interest Law Journal 49, 50.

58 Wizner, 'The Law School Clinic' (n 30) 1934.

59 Hurwitz, 'Lawyering for Justice' (n 32) 517.

60 Benjamin Hoffman and Marissa Vahlsing, 'Collaborative Lawyering in Transnational Human Rights Advocacy’ (2014) 21 Clinical Law Review, 261.
} 
rights norms. ${ }^{61}$ Moreover, when students have enhanced consciousness of the client's problems, they become more conscious of their responsibilities towards clients, which can develop into an enhanced awareness of their social responsibilities. ${ }^{62}$

Human rights lawyering requires analysing the politics of power and causation, and should be understood in terms of implications for specific rights of individuals. ${ }^{63}$ Lawyers working within these systems must learn to identify structural impediments and work towards changing social structures that cause and sustain injustice. ${ }^{64}$ Law students must learn how to go beyond merely enforcing the law, to be able to identify challenges in implementation at the same time, and the implications of implementing certain legislations for a group or society or an individual. Law graduates and lawyers must be able to describe issues in human rights terms, formulate demands using human rights tools, and develop advocacy and accountability for the most affected persons, ${ }^{65}$ and at the same time, must realise that social change lawyering is often perceived as radically, economically, and often politically biased. ${ }^{66}$ Thus, in order to successfully have a positive impact on society and influence public opinion, law students must develop a great deal of awareness of the system, stakeholders, and key partners. ${ }^{67}$ Wilson et al. emphasise that a contextual understanding of the popular sentiment is key to promoting change, and argue that in order to conduct a proper deconstruction, one must understand why a rights violation practice is supported by certain societies or individuals. ${ }^{68}$

This particular type of awareness of the system is necessary for lawyers, especially when working with vulnerable groups, because formal law has little impact on their rights. For example, despite gender neutralisation of laws in a large majority of the world's countries, inequality for women continues to exist. This is largely attributed to socio-cultural norms and values affecting rights of women, and unless these narratives and opinions can be changed, formal law will continue to have little impact on women's rights and family issues. ${ }^{69}$ Awareness of the system becomes particularly acute when working in a system such as the Maldives which has incorporated international human rights into its legislative framework, a system where the legal and judicial systems are fundamentally based on Islamic Shari'ah, and where core legal concepts of family, succession, and criminal law are entirely based on Islamic law. A thorough knowledge of all values and concepts — Islamic Shari'ah,

\footnotetext{
61 Harold Hongju Koh, 'How Is International Human Rights Enforced?' (1999) 74 Indiana Law Journal 1397, 1416.

62 Wizner, 'The Law School Clinic' (n 30) 1935.

63 Hurwitz, 'Lawyering for Justice' (n 32) 517.

64 Richard J Wilson, Jennifer Ramussen, and Scott Codey, Promoting Justice: A Practical Guide to Strategic Human Rights Lawyering (International Human Rights Law Group 2001) 55; also see Hurwitz, 'Lawyering for Justice' (n 32) 517.

65 Hurwitz, 'Lawyering for Justice' (n 32) 517.

66 Ibid. 519.

67 Wilson et al., Promoting Justice (n 64) 51.

68 Ibid. 54.

69 Jabyn, Local Implications of International Human Rights Treaties (n 10); Catherine Barnard and Bob Hepple, 'Substantive Equality' (2000) 59 (3) Cambridge Law Journal 562; Wilson et al., Promoting Justice (n 64) 97.
} 
the Maldivian legal system, and international human rights law — is therefore fundamental to embracing the essence of human rights lawyering in the context of the Maldives.

Social justice is a core value,$^{70}$ and is integral to teaching and instilling critical lawyering skills. Empathetic lawyering requires knowledge of others' experience, and sympathetic identification and cross-cultural collaboration'. ${ }^{71}$ Thus, human rights law is values-driven and invokes a sense of social justice in people who work with rights. ${ }^{72}$ Law students must therefore develop key skills such as compassion and empathy, because it is important for them to view the system from the standpoint of the client. With vulnerable groups, and particularly with clients with intersecting vulnerabilities, offering adequate and sufficient advice requires a holistic understanding of the case, from the perspective of the rights holder. ${ }^{73}$ This type of empathetic lawyering is best learned through human rights field work, ${ }^{74}$ and, by pursuing social justice goals and advancing human rights of vulnerable groups, university law clinics can benefit legal education and the society at large.

Many successful clinical programmes have thus been conducted to date, which has enhanced law student learning, and provided significant services to communities. Law school clinics have engaged in global fact-finding missions, impact litigation, legislative advocacy efforts, and concomitant report writing. ${ }^{75}$ Successful projects in the past have conducted fact-finding missions to investigate allegations of official harassment and persecution of judges and defence attorneys and their effect on the international rights to due process and fair trial, ${ }^{76}$ investigate women's property rights under customary law, ${ }^{77}$ and conduct on-site investigations. ${ }^{78}$ The Public Interest Law Clinic of the University of Los Andes in Bogota has engaged in factfinding, reporting, and impact litigation to advance the human rights of indigenous landowners, prisoners, pregnant women, and other vulnerable groups in Columbia. ${ }^{79}$ At the end of these missions and investigations, students prepare and disseminate

\footnotetext{
70 David Hall, 'Giving Birth to a Racially Just Society in the 21st Century' (1999) 21 University of Arkansas at Little Rock Law Review 927, 934.

71 Bond, 'The Global Classroom' (n 29) 332.

72 Hurwitz, 'Lawyering for Justice' (n 32) 522.

73 See Jane Harris Aiken, 'Striving to Teach "Justice, Fairness and Morality" (1997) 4 Clinical Law Review 1.

74 Bond, 'The Global Classroom' (n 29) 332.

75 Ibid.

76 Ibid, 321; Also see Joseph R. Crowley, 'Justice on Trial: State Security Courts, Police Impunity, and the Intimidation of Human Rights Defenders in Turkey' (1999) 22 Fordham International Law Journal 2129 describing the findings of the mission to Turkey.

77 Jeanmarie Fenrich and Tracy E Higgins, 'Promise Unfulfilled: Law, Culture, and Women's Inheritance Rights in Ghana' (2001) 25 (2) Fordham International Law Journal.

78 Bond, 'The Global Classroom' (n 29) 321.

79 See Daniel Bonilla and Colin Crawford (eds), Justicia Colectiva, Medio Ambiente Y Democracia Participativa (Universidad de los Andes 2009); Daniel Bonilla, 'Igualdad, orientación sexual y derecho de interés public: La historia de la sentencia C-075/07', en Parejas Del Mismo Sexo El Camino Hacia La Igualdad (2008) 11-40; United Nations Human Rights Committee, Report to the Human Rights Committee regarding Human Rights Violations of Detainees in Columbia (2010). http://www2.ohchr.org/english/ bodies/hrc/docs/ngos/LAU_FIU_Colombia.pdf. Accessed 25 November 2020.
} 
the findings in the form of a report. Yet many other projects collected interviews and gathered information from on-site visits and formed litigation strategies for cases before national and international courts. ${ }^{80}$

In neighbouring countries such as India, simple programmes such as visiting rural areas and providing information on government programmes to communities provide tremendous support to local communities in accessing governance and justice systems. ${ }^{81}$ One such successful programme is that conducted by SM Seghal Foundation in partnership with Jindal Global Law School (JGLS) which provides year-long training to local villagers and teaches them the functioning of the system and provides them with tools to monitor the system. The JGLS Good Governance and Citizenship Participation Clinic supports the efforts of villagers by providing governance training, including through panel discussions with government officials, policy advocacy based on problems identified in the field, legal aid camps in villages, and responses to bribe seeking and other forms of corruption that villagers encounter. The Clinic also hosts an annual conference on good governance and citizenship participation, and also provides training to other NGOs and academic institutions. ${ }^{82}$ The model also assisted law students to not only impart knowledge on the system, teach locals to prepare right to information applications, and write letters to government institutions, but at the same time undertake advocacy on their behalf, learning to interview and represent clients, ethical investigation, report writing, documentation, and empathetic lawyering, all at the same time. ${ }^{83}$ In the Philippines, successful clinical programmes have trained students to use participatory methods in representing clients. Different from the traditional lawyering approach which creates a system of 'client dependency on lawyers', this approach treats clients as co-decision-makers, and encourages self-reliance on the part of marginalised groups and empowers them to understand issues and find solutions for themselves. ${ }^{84}$ Law clinics in Japan have been successful in providing legal assistance to the expatriate population facing issues with marriage, divorce, child custody and support, immigration, and other contractual matters. Through the use of these clinical programmes, the needs of a large foreign residential population were met, and the law clinics were able to afford legal services to the members of these communities. ${ }^{85}$

The starting point for law clinics in the Maldives, similarly, could ideally be to attend to the legal needs of the socially disadvantaged groups. In many parts of the

\footnotetext{
80 Bond, 'The Global Classroom' (n 29) 322-323.

81 Shuvro Prosun Sarkar, 'Empowering the Underprivileged: The Social Justice Mission for Clinical Legal Education in India', in Sarkar, Clinical Legal Education in Asia (n 43) 182.

82 Ibid. 183.

83 Sital Kalantry, Elizabeth Brundige, Priya S Gupta, Cornell Law School International Human Rights Clinic, and JGLS Good Rural Governance and Citizen Participation Clinic, 'Promoting Clinical Legal Education in India: A Case Study of the Citizen Participation Clinic' (2012) Cornell Law Faculty Publications (Paper 1401) 11-13.

84 Carlos Medina, 'Law Schools and Legal Aid: The Philippines Experience' (South Asia CLE Conference, Phnom Penh, 26-30 November 2005), as cited in Lasky, 'Introduction: Clinical Legal Education and Its Asian Characteristics' (n 43) 6-7.

85 Mathew J Wilson, 'Legal Clinical Education in Japan', in Sarkar, Clinical Legal Education in Asia (n 43) 206 .
} 
Maldives, initial law clinics can focus on community and grassroots lawyering as opposed to a representation of clients in courts. This is also because there will be limited supervision, and supervising lawyers may not always be able to travel to the islands. While this would allow students to work towards broad legal social change, it would also allow them to research socially relevant issues and challenges at the individual and community levels. In terms of implementation, this will be a useful exercise, for instance, to identify why the level of knowledge on the Domestic Violence Act is higher, and why it is difficult to get protection orders in some parts of the Maldives.

Rethinking roles and adopting CLE programmes at local law schools in the Maldives, particularly those with campuses on the outer islands, can successfully realise both pedagogical and advocacy goals of law schools and the legal profession. Students working with qualified supervising lawyers can be engaged in factfinding studies, legal and non-legal advocacy, impact legislation, legislative advocacy efforts, reporting, and raising rights awareness in local communities, which will advance the rights of multiple vulnerable groups. These initiatives will also foster collaborative partnerships and teach human rights practice to students, while advancing human rights at the same time. Clinical work will be particularly enlightening for these students because it will heighten their experience, motivate them, and improve their lawyering skills through client contact. The engagement with rural communities will expose students to the macro aspects of lawyering, which will allow them to explore social justice issues and question the larger social purpose. ${ }^{86}$ Moreover, such clinical initiatives can cater to marginalised groups such as the Bangladeshi workers in the Maldives forming half of the local labour force, and provide services which otherwise get limited due to their being ineligible for the services, the language barrier, staffing constraints, or the inability to assist with longterm cases.

Thus, despite limitations and costs, clinical programmes in other parts of the world serving rural communities have proven that law school clinics can be based anywhere, and that their services can be provided through collaborative efforts with partner organisations. The outreach of such programmes to provide the muchneeded legal services, provides useful inspiration and guidance for human rights law clinics in the Maldives. While most clinical initiatives can be costly, the cost can be reduced through creating partnerships, which appears to be possible in the context of the Maldives, especially because law schools already have campuses in major population areas away from the greater Malé region. These law students in the atoll campuses can be attached to supervising lawyers based in Malé, and under their supervision, can take part in assisting clients with filling forms and making applications to courts.

Students can also work on law reform projects and make suggestions for proposed legislation. In recent times, Maldives has seen a sudden surge in social protection legislation, especially aimed at vulnerable groups suffering from abuse and

\footnotetext{
86 Carrie Menkel-Meadow, 'Two Contradictory Criticisms of Clinical Education: Dilemmas and Directions in Lawyering Education' (1986) 4 Antioch Law Journal 287, 288-289.
} 
violence. The benefits of such legislation, at times, are not within the reach of rural communities. Thus, students can be involved in developing human rights projects, and conduct grassroots lawyering which can assist with legal rights and empowerment. Such groups can also work with local leaders and key players in creating necessary policy changes in the country. Students in various law schools, although in limited ways, already work with NGOs in Malé to provide assistance to victims of sexual abuse, youth at risk, and the indigent.

The potential benefits of such a clinical initiative are relatively high in the context of the Maldives, because law clinics integrate macro and micro tools which build lawyering skills. Moreover, while learning the many aspects of lawyering, and the implementation of the law for social justice needs, students will also learn the gendered dimensions of law and the unique problems faced by women, such as gender-based violence, and the economic disadvantage of women, which affects their ability to pursue rights and justice at multiple levels. Furthermore, many clinical programmes are supported by national and international donors, ${ }^{87}$ and with the continuing interest shown by donor agencies in the Maldives, this appears to be a likely possibility for assisting with the challenge of resources.

\section{Conclusions: Critical considerations and recommendations}

Human rights law is ubiquitous and central to the fulfilment of justice, and therefore, new age law schools must contribute to the fulfilment of the legal profession's responsibility to enhance the capacity of institutions to do justice, and make this objective relevant for the next generation of lawyers. Differences in legal education exist everywhere in the world; however, by including the provisions of CLE, law schools can address the lack of experiential learning among students, and at the same time provide key training for students in human rights lawyering, fulfil the ethical and human dimensions of good lawyering, with a wider social justice objective. To this end, human rights law clinics offer enormous potential for law students, as well as social justice for vulnerable groups in the Maldives islands.

While the possibilities through law clinics are many, and must be given due consideration by the legal profession and legal educators, the potential for a sustainable law clinic within law schools appears to be low in the current context, and hence needs careful consideration. ${ }^{88}$ The same challenges continue to exist in the Maldives with the bulky law degree programme, clinical and experiential learning not being a mandatory part of legal education, not receiving credit for experiential learning programmes, teaching and management capacity, and the challenges with funding and resources. Such challenges are not unique to new clinics, and having a structured law clinic has been an issue in many Asian countries. ${ }^{89}$ Despite the length of established

\footnotetext{
87 See Shannon M Roesler, 'The Ethics of Global Justice Lawyering' (2010) 13 Yale Human Rights \& Development Law Journal 185, 186-187.

88 See Jabyn and Sterling, 'Better Lawyers, Better Justice' (n 46) 24-30.

89 Ibid.
} 
programmes, even older law clinics have problems of sustainability. The number one obstacle for the large majority of the law clinics continues to be the lack of resources. However, national and international funding can assist such programmes with hiring attorney staff, provide specialised training to law students, and assist with legal assistance to the communities. ${ }^{90}$ The lack of funding for such programmes may also be closely related to the second major obstacle to establishing law clinics, the acceptance of CLE programmes and the recognition that this method of legal education is the ideal method to train the next generation of legal professionals.

Clinics often select cases based on their pedagogical value, ${ }^{91}$ and therefore balancing teaching and project goals, managing diverse student experiences, geographic distances, multi-disciplinary project demands, recognising appropriate roles and limits, can also be key challenges in human rights clinical teaching and advocacy. ${ }^{92}$ However, a clinic in the atolls in the Maldives will need to focus on other activities for students that foster their capacity for moral indignation at injustice. ${ }^{93}$ Clinical hours will not often reflect the semester hours of a university; hence, clinicians will have to work outside the academic calendar to ensure services to clients. This means students who join clinics must be available for projects that span multiple semesters, but this may be a bit frustrating for students at the same time. Even then, it will not be possible to attend to every activity related to a case, such as attending court hearings and meeting other due dates, simply due to timing issues. ${ }^{94}$

Clinical supervisors must also ensure that the clinical experience balances the diverse interests and skill levels of the students joining the clinics. Many students join human rights clinics out of sheer interest in gaining more knowledge and obtaining live experiences, yet some others who join may arrive with a strong background in the field of human rights, as well as international human rights. ${ }^{95}$ Students must be able to 'quickly master the file, absorb the case history, understand the client and grasp the necessary law and procedure', if they are to gain the whole clinical experience. ${ }^{96}$ Law schools must also determine how much substance of human rights law needs to be covered in the clinics, or whether a background in international law or

\footnotetext{
90 Peggy Maisel, 'Expanding and Sustaining Clinical Legal Education in Developing Countries: What We Can Learn from South Africa' (2007) 30 Fordham International Law Journal 374, 397.

91 Kestenbaum et al., 'Catalysts for Change' (n 28) 468-469; also see Scott Cummings and Deborah Rhode, 'Public Interest Litigation: Insights from Theory and Practice' (2009) 36 Fordham Urban Law Journal 627; Also see, Arturo J. Carillo, and Nicolás E. Yaksic, 'Re-imagining The Human Rights Law Clinic' (2011) 26(1) Maryland Journal of International Law 80; '[Public interest] litigation, although a necessary strategy of social change, is never sufficient; it cannot effectively work in isolation from other mobilization efforts.' See also Henry J Steiner, 'The University's Critical Role in the Human Rights Movement' (2002) 15 Harvard Human Rights Journal 317, 326 (arguing that 'clinical projects in human rights should generally range more broadly than client representation in the courts and should shed their traditional court-centric character').

92 Kestenbaum et al., 'Catalysts for Change' (n 28) 468.

93 Stephen Wizner, 'Beyond Skills Training' (2001) 1 Clinical Law Review 327, 330.

94 Nancy Maurer, 'Handling Big Cases in Law School or Lessons from My Clinical Sabbatical' (2003) 9 Clinical Law Review 879, 891-892.

95 Kestenbaum et al., 'Catalysts for Change' (n 28) 470.

96 Maurer, 'Handling Big Cases in Law School' (n 94) 892.
} 
human rights should be made a prerequisite for clinic enrolment. ${ }^{97}$ Student interest also has an impact on the performance of the clinic and the clinical experience, ${ }^{98}$ and in order to successfully conduct clinical programmes, universities must ensure that the programmes are of value and interest to their student body. ${ }^{99}$

In the local context, interest in law school clinics can be sufficiently enhanced by making law clinic modules mandatory, credited, or by bringing the required changes to the Legal Profession Act. Establishment of law clinics must be made mandatory for every law school to have a functional clinic to work with local communities. Such clinics can be established by partnering with local NGOs and the Bar Council of the Maldives can also provide support to the clinics by providing technical support to law schools. Making clinical programmes a mandatory part of the legal education curriculum would also mean that clinical study will be credit-based, ensuring that students pay adequate attention and take modules seriously. Law schools must also have in-house clinical supervisors and clinical teachers so that clinical education can be developed and strengthened as a matter of institutional and educational development. The Bar Council of the Maldives can also help law schools to develop standardised clinical programmes, and at the same time inspect and monitor such programmes. Such initiatives will not only help develop relationships between existing and future lawyers, but also develop a sense of professional responsibility amongst both generations of lawyers. The experienced gained in the clinical programme can also be considered as supervised training for the purposes of the oneyear legal training provided for in the Legal Profession Act. Such a modification to the Act to allow law students to do supervised work that will contribute towards the legal requirement of legal training will be beneficial for both the law students and the legal profession in the long run.

Resistance from traditional-thinking members of the profession, law practitioners and legal educators alike, will continue to be a major part of the problem of introducing innovative ways of teaching and providing legal services. However, there is much to be learned from the clinical experiences of other countries, and what has been developed over decades, and there are sufficient practice modalities that can be adopted by the Maldives to introduce the first human rights law clinics.

Publisher's Note Springer Nature remains neutral with regard to jurisdictional claims in published maps and institutional affiliations.

\footnotetext{
97 Hurwitz, 'Lawyering for Justice' (n 32) 541.

98 Ibid. 535.

${ }^{99}$ See William L Berman, 'Why Not an International Clinical Legal Exchange Program — It Is Worth the Schlep' (2014-2015) 21 Clinical Law Review 171; Barry et al., 'Clinical Education for This Millennium' (n 39) 1.
} 